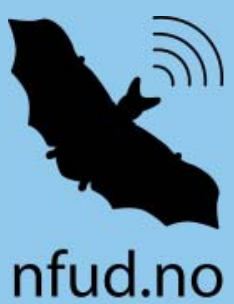

\section{NFUDs 42. symposium}

NFUD hadde sitt 42. symposium 18.-20. april. Møtet ble arrangert i Stavanger på Clarion Hotel Energy. Det var igjen et stort fokus på hands-on opplæring som ble mulig på grunn av tilgang til scannere, villige instruktører og modeller.

Prisen for beste frie foredrag på 10000 kr ble vunnet av Anesa Mulabecirovic fra Nasjonalt Senter for Gastrointestinal Ultrasonografi ved Haukeland Universitetssjukehus for sitt foredrag om måling av leverstivhet $i$ en frisk populasjon for to nye elastografimetoder. Nytt av året var en egen pris for beste kasuistikk på 5000 kr. Denne ble vunnet av Målfrid Møkkelgård ved Nasjonal behandlingstjeneste for avansert invasiv fostermedisin ved St. Olavs i Trondheim for presentasjonen: «Mor og foster med anemi og ødemer. Et tilfelle av Ballantynes syndrome og Pure Red Cell Aplasia». Fredrik Sævik ble tildelt Forskningsstipendet på kr. 10000 ,- til sitt prosjekt: «Validation and interobserver reliability on an ultrasonographic score for the assessment of disease activity in Crohn's disease».

Styret gratulerer alle prisvinnerne.

På generalforsamlingen ble økonomi et viktig tema. NFUD mistet to sponsorer like før årsmøtet. Det er viktig å ha en sunn økonomi før Euroson 2020 som skal arrangeres i Bergen. Flere tiltak ble foreslått for å oppnå dette. Tidligere har man planlagt årsmøtet med et lite underskudd for å føre noe av kontingentinntektene tilbake til medlemmene. I 2019 vil styret forsøke å la årsmøtebudsjettet gå i balanse. Det ble dessuten fremsatt at det skal arbeides mer aktivt med å få inn andre sponsorer. Kontingenten ble økt fra 600 kr til 650 kr mens studentprisen ble redusert til 100 kr. En viktig lovendring ble endelig vedtatt etter 2 . gangs behandling av generalforsamlingen. Endringen består i at fremtidige lovendrin- ger nå kan vedtas direkte med 2/3 flertall på en ordinær Generalforsamling. Tidligere måtte minst $50 \%$ av medlemmene møte på generalforsamlingen for at denne kunne bli beslutningsdyktig og dette virket svært konserverende.

Det var ikke valg av nytt styre i år, men en ny valgkomite ble valgt. Denne består av Roald Flesland Havre (leder), Hilde Berner Hammer, Bjørn Angelsen, Claudia Heien og Vivi Bakkeheim. Ønsket om en egen jordmordag under symposiet ble også diskutert, og det var enighet om at styret skal arbeide for å sette av mer tid i symposiet til tema som er direkte rettet mot jordmødrene uten at det går for mye på bekostning av tverrfagligheten.

Ultralyd er kontaktsport og hands-on-sesjon i akuttmedisinsk ultralyd bragte deltagere fra hele landet sammen om undersøkelse av pasienter med tungpust, magesmerter, hovent ben, brystsmerter og lavt blodtrykk. Sesjonen var godt besøkt og diskusjonen om hvordan vi skal diagnostisere de sykeste pasientene våre gikk hett langt inn i pausene og lunsjen.

MSK-sesjonene var godt besøkt takket være gode, engasjerte forelesere og hands-on instruktører. Spesielt hands-on-sesjonene var populære, der vi blant annet fikk demonstrert ultralyddiagnostikk av skulderledd sett med øyne til forskjellige spesialiteter (fysikalsk medisin, radiologi og revmatologi). Øvrige regioner som ble demonstrert var hofte, ileosakralledd og ankel. Flere pasienter stilte villig opp som modeller for demonstrasjon av patologiske funn. Emner på forelesninger var det alltid relevante temaet «injeksjon i skulderledd» og det nyttige tema om bløtdelstumorer.

Sesjonen hadde flere spennende foredrag med internasjonalt anerkjente forelesere.

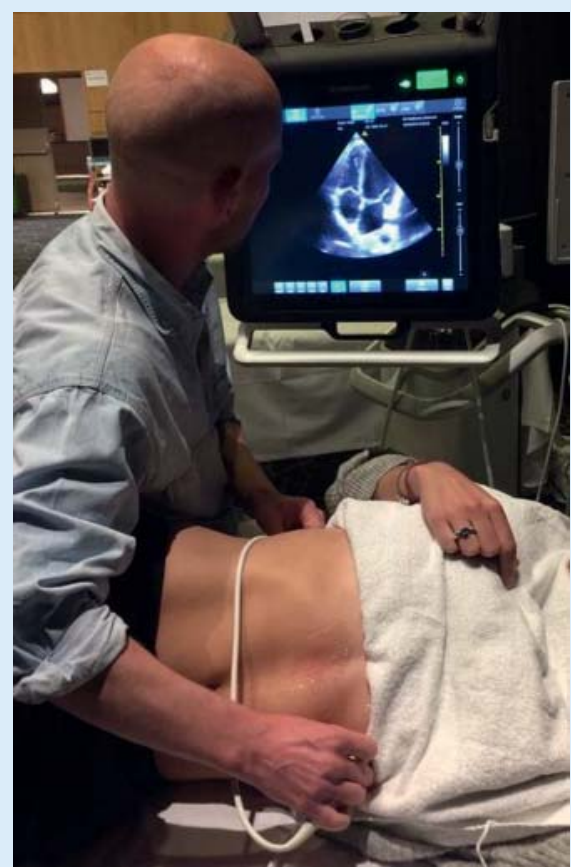

Et stemningsbilde fra en hands-on-sesjon for ultralyd i legevakt og akuttmottak.

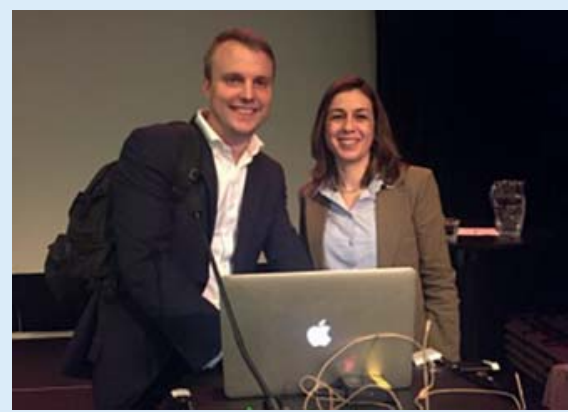

Dina Ismail og Wouter Froymann.

Symposiet hadde i år mer gynekologi enn tidligere, med foredrag som ble godt mottatt.

Wouter Froymann, fra Universitetssykehuset Leuven i Belgia, gav med sitt foredrag "Diagnostic methods in classification of ovarian masses» en innføring i arbeidet til 
IOTA-gruppen (The International Ovarian Tumor Analysis). Davor Jurcovic, fra University College Hospital, London, holdt også et interessant foredrag om «Ultrasound strategy in endometriosis/endometrioma in pregnancy» og «non-tubal-pregnancy.»

Dina Ismail viste videre hvordan 3D-ultralyd benyttes i gynekologien. Tina Tellum gav en innføring i tilstanden adenomyose og videre et flott foredrag om «one-stop fertility workup with ultrasound.»

Harm-Gerd Blaas' foredrag om embryologi og sonoembryologi viste betydningen av kunnskap om den embryologiske utvikling av CNS ved de ulike gestasjonsaldre i forhold til å kunne vurdere den neurosonografiske undersøkelsen. Ultralydundersøkelsen av fosterhjernen ved Aurora Røset, Torbjørn Eggebøs innlegg om «Bordeline ventrikulomegali» og Bodil Hvingels "Posterior fossa anomalier» ble fulgt med "live scan.» Claudia Heiens innlegg gjorde oss sikrere i diagnostisering av missed abortion. Torbjørn Eggebø gav en innføring i metoden NIPT (Non Invasive Prenatal Testing) som er kommet som en "ekstra screeningtest» i tilbudet om fosterdiagnostikk.
Det bør også nevnes at symposiet ble godt besøkt av allmennleger som utgjorde cirka 30 stykker av deltagerne. Dette ble spesielt tydelig den siste dagen da man skulle diskutere "Hvem skal gjøre hva med ultralyd.» I panelet satt Nils Petter Oveland, Kari Utne, Åse Tangerud, Victoria Vatsvåg og Morten Glasø. Erik Andreas Torkildsen var moderator og fikk i gang en god diskusjon hvor allmennlegene bidro engasjert. Om man ikke ble helt enige i alle spørsmålene som kom opp, kom det i hvert fall klart frem at man trenger et forum som NFUD for å møtes også i fremtiden. 